\title{
THE IMPACT OF THE NON-DISTRIBUTION CONSTRAINT AND ITS ENFORCEMENT ON ENTREPRENEURIAL CHOICE, PRICE, AND QUALITY
}

\author{
Petra Brhlíková \\ Andreas Ortmann
}
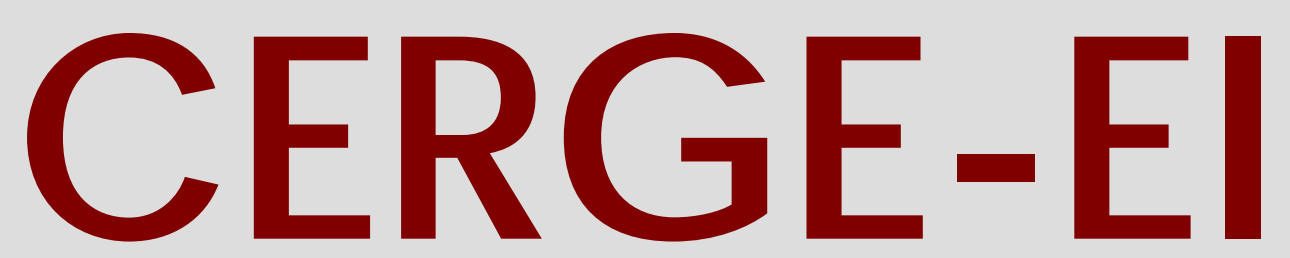

Charles University Centerfor Ec onomic Research and Graduate Educ ation Academy of Sciences of the Czech Republic Ec onomic Institute 


\section{Working Paper Series 299 (ISSN 1211-3298)}

\section{The Impact of the Non-distribution Constraint and Its Enforcement on Entrepreneurial Choice, Price, and Quality}

Petra Brhlíková

Andreas Ortmann

CERGE-EI

Prague, July 2006 


\title{
The Impact of the Non-distribution Constraint and Its Enforcement on Entrepreneurial Choice, Price, and Quality*
}

\author{
Petra Brhlíková and Andreas Ortmann ${ }^{\dagger}$ \\ CERGE-EI ${ }^{\ddagger}$
}

July 2006

\begin{abstract}
We study the conditions under which it is rational for a representative entrepreneur to start a nonprofit firm. Taking as point of departure a model of entrepreneurial choice proposed by Glaeser and Shleifer (2001), we analyze consequences of weak enforcement of the non-distribution constraint on entrepreneurial choice and price and quality of the product. We find that the nonprofit organizational form becomes unequivocally more attractive to entrepreneurs if enforcement of the non-distribution constraint is weak. We also find that the quality delivered by nonprofit firms is lower under weak enforcement than that of the nonprofit firm under strict enforcement, but higher than the quality delivered by a for-profit firm. We discuss the implications and limitations of our results.

Abstrakt

Studujeme podmínky, za kterých je pro podnikatele racionální založit neziskovou firmu. Vycházejíc z modelu navrženého Glaeserem a Shleiferem (2001) analyzujeme důsledky slabé vynutitelnosti principu nerozdelování zisku pro rozhodování podnikatelů mezi ziskovou a neziskovou formou, kvalitu a cenu produktů. Zjištujeme, že nezisková forma se stává atraktivnejší pro podnikatele pri slabé vynutitelnosti principu nerozdelování. Také zjištujeme, že kvalita poskytována neziskovými firmami pri slabé vynutitelnosti principu nerozdelování je nižší než kvalita poskytována neziskovými firmami pri úplné vynutitelnosti, ale vyšší než kvalita poskytována ziskovými firmami. Diskutujeme implikace a omezení našich výsledků.
\end{abstract}

Keywords: Entrepreneurial choice, Nonprofit, For-profit, Non-distribution constraint, Enforcement

JEL classification: D2, L2, L31, K42

\footnotetext{
*We thank Richard Steinberg for insightful comments. Petra Brhlikova acknowledges financial support provided by GAUK (grant no. 457/2004).

${ }^{\dagger}$ Email: Petra.Brhlikova@cerge-ei.cz, Andreas.Ortmann@cerge-ei.cz

$¥$ A joint workplace of the Center for Economic Research and Graduate Education, Charles University, Prague, and the Economics Institute of the Academy of Sciences of the Czech Republic. Address: CERGE-EI, P.O. Box 882, Politických vězňů 7, Prague 1, 111 21, Czech Republic
} 


\section{Introduction}

In developed countries, the nonprofit, or third, or civil sector is among the two or three largest industries (Salamon, Anheier, and Associates 1999). While this fact provokes important questions about private power in a democracy, the nonprofit sector typically draws on a long history of accomplishments and is generally acknowledged to set the pace in social services as well as social innovations (Hall 1992).

Downplaying to some extent their public benefit rationale (e.g. Weisbrod 1988) and building on theories of asymmetric information (e.g. Akerlof 1970), Hansmann (1980) explained the existence of nonprofit (NP) organizations as institutions that evolved in response to informational asymmetries in what is sometimes called "trust markets": Markets in which the quality of a good or service is ex ante difficult or unreasonably costly to assess, and in which consumers, or donors, hence have to trust the provider to deliver the quality that was promised (Ortmann and Colander 1997). Consumers' lack of information thus opens the door for various forms of ex post expropriation. Ignoring the possibility of a reputational solution (e.g. Heal 1976), Hansmann (1980) argued that the non-distribution constraint ${ }^{1}$ - arguably the most prominent characteristic of NP firms all over the world, and throughout history - weakens the incentives of NP entrepreneurs to maximize profit at consumers' expense. Thus NP entrepreneurs, by their choice of ownership form, can constrain their future options and signal their trustworthiness.

In reality, however, the definition of what constitutes non-distribution often does not form a particularly binding constraint, making perk consumption (a plush office that the NP entrepreneur might value almost as much as the cash value it

\footnotetext{
${ }^{1} \mathrm{~A}$ non-distribution constraint allows a nonprofit firm to make profits but does not allow it to distribute profits to managers or employees. Whatever surplus a nonprofit generates ought to be ploughed back into the quality of its products or ought to be used to finance provision of the firm's services to indigent parts of the population.
} 
represents, or the additional power and prestige that comes with a staff larger than really needed, or credit cards that are generously used for questionable purposes) quite possibly an important part of a compensation package. Moreover, even excessive perks rarely violate laws and regulations (e.g., those defining the "fiduciary duty" of nonprofit board members).

Moreover, the non-distribution constraint, as weakly binding as it is, is often only weakly enforced and there are thus many temptations to circumvent this laudable requirement (e.g. Ortmann and Schlesinger 2003; Gibelman and Gelman 2004. While recent debates in the U.S. have demonstrated that even in developed countries enforcement is a persistent problem (e.g. Bradley, Jansen, and Silverman 2003; Senate Finance Committee Staff 2004), our analysis is motivated by the well-known and pervasive problems of enforcement in developing and transition economies (Roland and Verdier 2003). The size and importance of the nonprofit sector in the Czech Republic, for example, lags behind NP sectors in western countries (Salamon, Anheier, and Associates 1999; Brhlikova 2004b). This may be due to its shorter history but very likely also due to the insufficient conditions for its evolution. Brhlikova (2004b) documents how the relevant legislation evolved in irregular spurts and almost always in a reactive manner tried to address problems that had become too obvious to ignore.

The nature of changes in legislation and spotty enforcement attracted, for example, "for-profit-in-disguise"2 entrepreneurs to the Czech NP sector, affecting its credibility, the donations it managed to collect, and thus contributing to its relatively slow development. One particularly striking example was the number of foundations very likely founded by "for-profit-in-disguise" entrepreneurs. Fric and Goulli (2001) track the number of foundations through the mid- and late nineties

\footnotetext{
${ }^{2}$ The term "for-profit-in-disguise" was introduced by Weisbrod (1975) to describe alleged nonprofit entrepreneurs motivated by profits who enter the nonprofit sector to exploit breaks bestowed on NPs, i.e. entrepreneurs whose motivations are not of the kind typically attributed to NP entrepreneurs (Young 1983).
} 
and report that the number was cut from about 5,000 to less than 300 in response to a more strict legislative intervention in 1998. Probably for similar reasons of insufficient legislation and regulations, the NP sector in the Czech Republic is overwhelmingly populated by civic associations - the least restrictive NP legal form. In 2002 there were about 49,000 civic associations comprising $88 \%$ of NP entities in the Czech Republic (Brhlikova 2004b). This is a considerable share of "unrestricted" and uncontrolled institutions even though these numbers are likely to be overestimated because civic associations are not required to provide information about their termination. ${ }^{3}$

Another problem is related to lack of transparency and information on NP entities (Ortmann, Svitkova, and Krnacova 2005). NP entities such as foundations, foundation funds, and public benefit organizations are required by law to submit annual reports to their respective regional courts. However, in 2002 only $48 \%$ of foundations, $26,6 \%$ of foundation funds, and in $200310 \%$ of public benefit organizations fulfilled their duty (CVNS 2004; CVNS 2005). Moreover, these two studies revealed that submitted documents are often of low quality and incomplete. For instance, from those organizations that submitted their annual reports one third of foundations and foundation funds and two thirds of public benefit organizations did not provide required information on assets and liabilities. To date, no organization neglecting the submission requirement has been punished.

Considering the de facto nonexistent enforcement of a constraint that is already not particularly binding, it does not seem surprising that many entrepreneurs entered the NP sector to exploit the subsidies and various breaks bestowed on NPs (Facchina, Showell, and Stone 1993). Below we study theoretically the conditions under which it is rational for a representative entrepreneur to start a NP firm even if it would mean constraining her future options. Specifically, we analyze the impact

\footnotetext{
${ }^{3}$ According to estimates about one third of these entities was not active in 2002 (USAID 2002).
} 
of weak enforcement of the non-distribution constraint on entrepreneurial choice and consequently on the price and quality of the goods and services provided by NP firms.

Previous authors concerned with issues of entrepreneurial choice (e.g. Eckel and Steinberg 1993; Bilodeau and Slivinski 1998; Glaeser and Shleifer 2001) have not addressed the consequences of weak enforcement. We address this blind spot in the literature by using as point of departure a model by Glaeser and Shleifer (2001). These authors formalize Hansmann's asymmetry theory in a simplistic but effective manner. They assume that entrepreneurs incur nonmonetary costs related to cheating on quality. Due to the non-distribution constraint faced by NP entrepreneurs, these nonmonetary costs have a higher impact on NP entrepreneurs, who have therefore less incentives to exploit informational asymmetries than FP entrepreneurs. The model shows that the NP ownership is attractive also to selfinterested entrepreneurs. In general, the NP ownership form is more advantageous in markets where quality is valued by consumers.

Modifying the basic framework of that model, we introduce subsidies to NP production and weak enforcement and definition of the non-distribution constraint. These two factors, in our view, affect the entrepreneurial choice between NP and FP ownership form. Subsidies to NP production in our model represent not only state subsidies and donations but include also tax and regulatory breaks given to NPs. These advantages reduce the competitive pressure on NPs in comparison to their FP counterparts and create opportunities for inefficiency in NP organizations (Newhouse 1970; Rose-Ackerman 1996). Such inefficiency is most probably reflected in better working conditions or other nonmonetary benefits that might be attractive to entrepreneurs and therefore affect the entrepreneurial choice between the NP and FP sector.

The non-distribution constraint and its enforcement are likely to influence the 
entrepreneurial choice even more significantly. The non-distribution constraint defines the rules of the game: it distinguishes between perks that are admissible and those that are not, i.e., it specifies the level to which perk consumption is allowed by law. Enforcement of the non-distribution constraint represents the level to which activities of NPs are checked for compliance with the rules of the game. Enforcement, therefore, applies only to perks that are not admissible by law, reducing their value to NP entrepreneurs.

Here we demonstrate, given a possibly insufficient definition of the non-distribution constraint, the importance of enforcement to keep the NP sector credible and to make sure that NP institutions can play the corrective role in society that prevailing theories of NPs assign them: subsidies and breaks bestowed on NPs ought to translate into a higher quality or lower prices of products and services in comparison to what FPs offer.

Our model reveals, perhaps not surprisingly, that the NP sector is more attractive to entrepreneurs when NP production is subsidized. Also, weak enforcement of the non-distribution constraint makes the choice of NP form more likely, thus providing a theoretical rationale for the empirical facts enumerated above. In line with our intuition, weak enforcement also has negative consequences for the quality offered by NP firms: NP firms deliver lower quality than NP firms under strict enforcement of the non-distribution constraint but higher quality than FP firms. This latter result differs from suggestions in some of the literature that weak enforcement would entirely eliminate the distinctive performance of legitimate NP firms. Steinberg (1993), for example, suggests that under weak enforcement only for-profits-in-disguise can survive, implying that the quality offered in the NP sector is the same as would be produced by the FP sector. He, however, does not formally model the issue.

The remainder of the paper is organized as follows: in the second section, we 
correct and then extend a model proposed by Glaeser and Shleifer (2001). Specifically, we derive under what enforcement conditions it is better for an entrepreneur to start a NP firm. In the third section, we discuss the implications and limits of our model. Concluding remarks follow.

\section{Entrepreneurial Choice}

The model in this section extends the model proposed by Glaeser and Shleifer (2001). ${ }^{4}$ It is a three-stage game whose key feature is ex post expropriation. The ownership status decision is made in the first stage of the game. Following the basic rationale of Hansmann (1980), in the second stage the entrepreneur sells a product of non-verifiable quality to a consumer. In the last period, the entrepreneur chooses quality and delivers the product.

The inverse demand function is represented by $P=z-m\left(q^{*}-q\right)$, where $z, m$, and $q^{*}$ are constants. Demand depends on $m$, which measures marginal willingness to pay for quality and on the difference between standard quality, $q^{*}$, and consumers' expectations about quality that will be delivered, $q$.

The utility function of an entrepreneur, whether of the NP or FP variety, is equal to Income $+V(Z)-b\left(q^{*}-q\right)$, where $Z$ is profit which, because of the non-distribution constraint, can be consumed by NP entrepreneurs as perks only. Hence, the utility function of a NP entrepreneur takes the specific form of Income $+V(Z)-b\left(q^{*}-q_{n}\right)=$ Income $+f(d, e) Z-b\left(q^{*}-q_{n}\right)$, where the constant $b$ represents costs associated with delivering a lower quality than promised. These costs can be interpreted in

\footnotetext{
${ }^{4}$ There are a few typos in the original paper. On p. 105, proposition 2 part (A), " $m^{*}=\frac{(1-d) z+b\left(q_{f}-q_{n}\right)-c\left(q_{f}\right)-d c\left(q_{n}\right)}{(1-d) q *-q_{f}+d q_{n}}$ " is wrong and should be replaced by " $m^{*}=$ $\frac{(1-d) z+b\left(q_{f}-q_{n}\right)-c\left(q_{f}\right)+d c\left(q_{n}\right)}{(1-d) q *-q_{f}+d q_{n}}$." The statement in this proposition 2 part (A) "below which all entrepreneurs choose non-profit status and above which all entrepreneurs choose for-profit status" should be "above which all entrepreneurs choose non-profit status and below which all entrepreneurs choose for-profit status", and on p. 105, proposition 2 part (B), "...m* falls and non-profit status..." should be "... $m^{*}$ rises and non-profit status...." Obviously, this leads to a different interpretation of $m^{*}$.
} 
two ways. First, as a nonmonetary (or psychic) cost that the entrepreneur incurs when delivering a lower quality than promised. Second, as a reputational cost that has monetary consequences. This latter interpretation recaptures the arguments by Heal (1976) and Klein and Leffler (1981) in a simple and straightforward manner. $f(d, e) \in(0,1]$ represents the value of perks as a fraction of profit, $Z$, that equals price received minus production costs. $f(d, e)$ depends on two parameters, $d$ and $e$. Following Glaeser and Shleifer (2001), $d$ denotes the value of perks for which they assume that it is always less than $1 . e$ (which is not part of their model) denotes the degree of enforcement of the non-distribution constraint, with $e$ possibly constraining the extent to which perks can be enjoyed even further (e.g., the kind of examples in Gibelman and Gelman 2004).

As mentioned in the introduction, perk consumption may be an important part of a manager's compensation package. The value it can take is a function of how binding the non-distribution constraint is defined. Enforcement, e, stands for the attempt of the authorities to make relevant laws and regulations binding and to punish violators. Models of crime, tax evasion, and the like, typically model enforcement through penalties and probabilities of being caught (and having the penalty imposed). We choose a simplistic way to model enforcement that can be conceptually rationalized by agents that are risk neutral and take into account the expected value of penalties and probabilities. We normalize the range of expected values to the unit interval, implicitly assuming that maximal enforcement brings perks close to zero.

The more stringent the enforcement of the non-distribution constraint is, the less the NP entrepreneur will be able to enjoy the resulting amenities. Thus, $f_{d}>0$ and $f_{e}<0$. Under weak enforcement the value of perks not covered by a non-distribution constraint, i.e. inadmissible perks, may reach the cash benefits level, $f(d, e)=1$. (Nothing would be lost if we would constrain $f$ to the open unit 
interval.)

To illustrate the relation between the non-distribution constraint, enforcement, and the entrepreneurial valuation of perks let us first assume that the legal definition of the non-distribution constraint allows only perks with zero valuation to the entrepreneur. It is useful to ponder the consequences of $d$ and $e$ being equal to 0 and/or equal to 1 . Clearly, these realizations of $d$ and $e$ describe four limit cases. The first case, $d=1$ and $e=0$, captures the scenario where the value of the perks is not at all constrained by enforcement of the non-distribution constraint. Hence, $f(d, e)=1$. The second case, $d=0$ and $e=0$, captures a scenario where the value of the perks is not at all constrained by enforcement of the non-distribution constraint either. In this case the lack of enforcement is inconsequential since perks are not valued in the first place. The remaining cases, $d \in\{0,1\}$ and $e=1$, capture scenarios where the enforcement is unrelenting and therefore perks (even though they might have value) can't be enjoyed. Hence, $f(d, e)=0$, or to be precise close to 0 since we assume that $f(d, e)>0 .^{5}$

To illustrate the situation for $d$ and $e$ between 0 and 1 we consider $f(d, e)$ linear in both variables (see Figure 1).

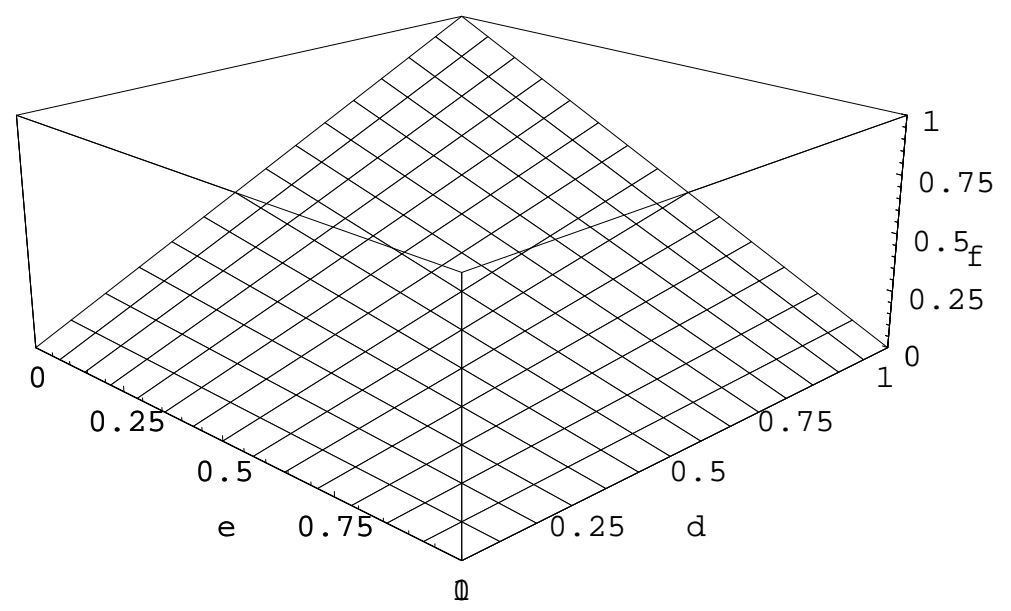

Figure 1: Value of perks with $N D C$ set at $d=0, f(d, e)=d(1-e)$

\footnotetext{
${ }^{5}$ Complete enforcement for the non-distribution constraint set at $d=0$ is prohibitively costly.
} 
Interestingly, given our functional specification of $f(d, e)$ we see that the value of perks is strictly smaller than one (smaller than the value of cash) for strictly positive enforcement irrespective of the individual valuation of perks $d$.

Recall that we are interested also in cases when the non-distribution constraint is not binding, i.e. it permits the consumption of perks with a positive value to entrepreneurs. Figure 2 depicts $f(d, e)=\min \{d, \max \{N D C,(1-e) d\}\}$ for $N D C$ (non-distribution constraint) set at $d=0.2$. Now, perks are consumed even under strict enforcement of the non-distribution constraint, but these are only the perks permitted by law and regulations. Entrepreneurs with the valuation of perks admissible by the non-distribution constraint always consume the fraction of profit that equals their valuation irrespective of the enforcement level. For $d>0.2$ and $e<1$ the value of $f(d, e)$ increases linearly in $d$ and $e$ as in Figure 1. Consider, for instance, an entrepreneur with $d=0.7$. He is willing to consume more perks than is permitted by the non-distribution constraint, i.e. he is thus interested in inadmissible perks. How much of inadmissible perks he in fact consumes depends on the enforcement level: under nonexistent enforcement $(e=0)$ he consumes a fraction of the profit $(0.7)$, a moderate enforcement of $e=0.5$ reduces the fraction to 0.35 , which is still above the level of the non-distribution constraint level, and strict enforcement $(e=1)$ he can consume only the fraction that is allowed by the non-distribution constraint, 0.2 .

Having explained the effect of the non-distribution constraint and its enforcement on perk consumption, we proceed by solving the entrepreneurial choice problem backward. In the third period both entrepreneurs take the price as given. FP entrepreneurs maximize $P-c\left(q_{f}\right)-b\left(q^{*}-q_{f}\right) \Rightarrow$ FOC: $c^{\prime}\left(q_{f}\right)=b$. NP entrepreneurs face the non-distribution constraint and receive subsidies, $s \in(0,1)$, which are assumed to lower the production costs that need to be covered by consumers' payments. NP entrepreneurs therefore maximize $f(d, e)\left[P-(1-s) c\left(q_{n}\right)\right]-b\left(q^{*}-q_{n}\right) \Rightarrow$ 


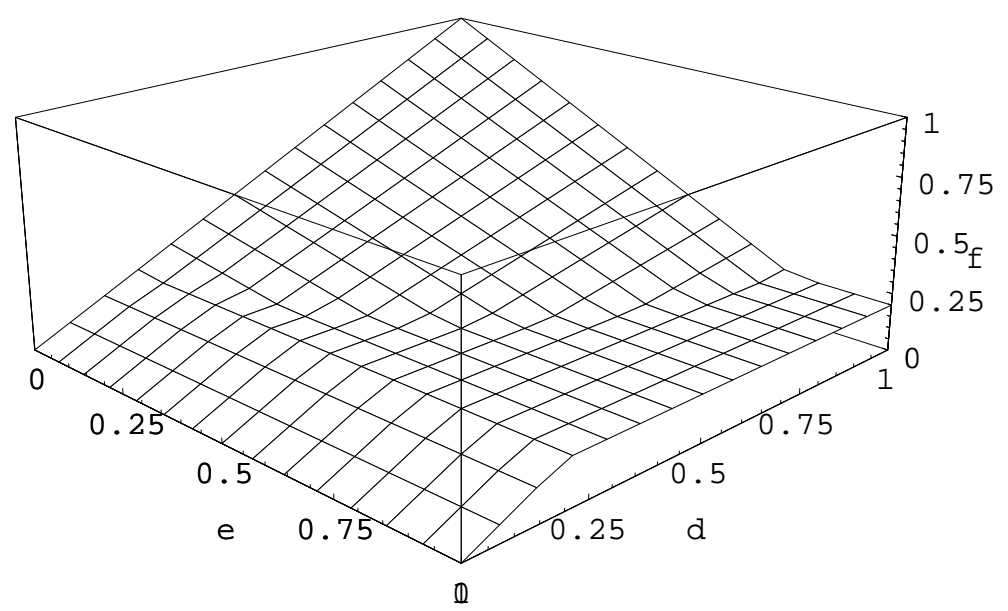

Figure 2: Value of perks with $N D C$ set at $d=0.2, \quad f(d, e)=$ $\min \{d, \max \{N D C, d(1-e)\}\}$

FOC: $c^{\prime}\left(q_{n}\right)=\frac{b}{(1-s) f(d, e)}$. ${ }^{6}$ We assume that $c^{\prime}(\cdot)$ is an increasing function. In addition to Glaeser and Shleifer we model subsidies and tax and regulatory breaks bestowed on NPs. These breaks are realized in our model in the form of a subsidy, $s^{7}$.

Proposition 1. The non-verifiable quality of the product of the NP firm exceeds that of the FP firm.

Proposition 1 follows from the FOCs and the convexity of the cost function.

\section{Proposition 2.}

- The subsidy causes the enhancement of the quality of products provided by the NP firm.

- The quality of NP products decreases when the valuation of perks, d, increases.

- The quality of NP products decreases, as enforcement of the non-distribution constraint weakens.

\footnotetext{
${ }^{6}$ Setting $s=0$ and ignoring the possibility of weak enforcement we would get Glaeser and Shleifer's model.

${ }^{7}$ Although subsidies are assumed to include also tax breaks bestowed on NPs, we assume that breaks do not affect the profit but only production costs of a NP firm. This way of modeling the problem reflects the fact that NPs use various resources for their production and do not live only on consumers' purchases for products and services.
} 
The results summarized in Proposition 2 follow from the FOCs and the fact that $c^{\prime}(\cdot)$ is an increasing function. The first part of the proposition relates to the effect of subsidy on quality produced. The increase in subsidy, $s$, induces higher quality of NP products due to the fact that subsidies are assumed to decrease production costs of NP firms. Note that an increase in $s$ has qualitatively the same effect as a decrease in $f(d, e)$ which may be triggered either by increased enforcement or decreased valuation of perks by NP entrepreneurs, or a linear combination of the two. Assuming that NP entrepreneurs' valuation of perks is stable, the interesting trade-off is between the costs of increased enforcement and the costs of tax and regulatory breaks.

Second, for a given level of enforcement, $f(d, e)$ increases in $d$ and therefore $q_{n}$ declines. If the value of perks rises, NP entrepreneurs have incentive to deliver a lower quality than promised. This seems in line with intuition.

Third, weak enforcement prompts for-profits-in-disguise to emerge. With decreasing enforcement, alleged entrepreneurs exploit market asymmetries and decrease quality. In addition, for $f(d, e)$ defined as $\min \{d, \max \{N D C,(1-e) d\}\}$, the quality of NP products decreases with a higher value of perks allowed by the non-distribution constraint. The effect of non-distribution constraint and its enforcement, too, seem in line with intuition and explain the observations (Fric and Goulli 2001; CVNS 2004; CVNS 2005) that motivate our study.

Continuing to solve backward, in the second period consumers pay $P$ for the product. In equilibrium consumers correctly anticipate the quality of products, therefore their willingness to pay in the second stage is higher when dealing with the NP firm than when purchasing the FP product. NP firms thus charge higher prices in equilibrium. This result is in line with the theoretical findings of Hirth (1999).

In the first period entrepreneurs opt for the ownership form by comparing the 
benefits of being either NP entrepreneur or FP entrepreneur. If $\left[f(d, e)\left(z-m\left(q^{*}-\right.\right.\right.$ $\left.\left.\left.q_{n}\right)-(1-s) c\left(q_{n}\right)\right)-b\left(q^{*}-q_{n}\right)\right]-\left[z-m\left(q^{*}-q_{f}\right)-c\left(q_{f}\right)-b\left(q^{*}-q_{f}\right)\right]>0$, then entrepreneurs will become NP entrepreneurs. Ultimately, entrepreneurs' choice of ownership form is determined by the value that $m$ takes.

Proposition 3. There is a unique value of

$$
m^{*}=\frac{(1-f(d, e)) z-b\left(q_{n}-q_{f}\right)-c\left(q_{f}\right)+f(d, e)(1-s) c\left(q_{n}\right)}{\left(q^{*}-q_{f}\right)-f(d, e)\left(q^{*}-q_{n}\right)}
$$

above (below) which all entrepreneurs choose NP (FP) status. ${ }^{8}$

The intuition is the following: FP firms will dominate markets for goods whose quality is not valued much by consumers, i.e. when $m$ is small. If consumers do care about quality (i.e. $m$ is high) the market will be dominated by NP firms. Consumers who value quality are willing to pay a higher price (schools, hospitals, nursing homes). Entrepreneurs want to charge higher prices to maximize their own utility. Charging the high price is, however, profitable only for NP firms. NP firms do not have incentives to adjust quality downward ex post, thus do not incur a loss in the form of non-cash costs $b\left(q^{*}-\hat{q}\right)$. Note that the tradeoff depends on the value of the parameter $b$. Of course, all this is moderated by the value that $f(d, e)$ takes as stated in Proposition 2.

Alternatively, the results of the model could be interpreted through the critical value of $f(d, e)$ and thus focus more on the entrepreneurial choice within a certain industry rather than on industries where either NP or FP ownership form is prevalent. Focusing on the entrepreneurial type, there is $d^{*}$ such that $f\left(d^{*}, e\right)=\frac{z-m\left(q^{*}-q_{f}\right)-c\left(q_{f}\right)-b\left(q_{n}-q_{f}\right)}{z-m\left(q^{*}-q_{n}\right)-(1-s) c\left(q_{n}\right)}$. If entrepreneurs differ in their subjective valuation of perks, i.e. have different $d$, then those entrepreneurs with $d>d^{*}$ would opt for the NP form and those with $d<d^{*}$ would prefer the FP form under certain

\footnotetext{
${ }^{8}$ The value of $m^{*}$ is now smaller than indicated by Glaeser \& Shleifer's model due to the subsidy that makes the NP status more attractive.
} 
market conditions given by $m, e$, and $N D C$.

In the NP sector we would therefore expect those entrepreneurs that have a high valuation of perks and are thus more prone to enjoy perks at the expense of providing high quality.

\section{Discussion: Limits of the Model}

Our extended version of Glaeser and Shleifer (2001) shows the conditions under which a self-interested entrepreneur opts for NP status. The conditions are formulated for a representative entrepreneur and consumer sensitivity to quality that is assumed to be homogeneous for a market, or industry segment. Thus, the resulting markets, or industry segments, are either all NP or all FP.

In reality, however, the two ownership forms often coexist within one industry (e.g. health care or education): The NP and the FP ownership do attract entrepreneurs within the same market, or industry segment. It would be desirable to introduce heterogeneity, either on the supply side, or the demand side, or both. For example, if valuation of perks were distributed in some manner, those entrepreneurs with high valuations of perks would likely end up as nonprofit entrepreneurs while those with low valuations would likely be better off as FP entrepreneurs. Likewise, if the marginal willingness to pay for quality were to differ among consumers, those consumers that do not value quality much are likely to be served by FP firms, while those that do are likely to be served by NP firms. This is supported by empirical evidence on day care centers and nursing homes provided by Mauser (1998) and Holtmann and Ullmann (1993) respectively.

The competition between NP and FP firms was analyzed in various settings; Liu and Weinberg (2004) and Lien (2002) focus on Cournot competition with homogeneous consumers. Friesner and Rosenman (2001), Harrison and Lybecker (2005), and Brhlikova (2004a) analyze modified Bertrand competition with firms compet- 
ing over price and quality. Consumers in Friesner and Rosenman (2001) differ in whether they are insured or self-paying, Brhlikova (2004a) assumes consumers with heterogeneous taste for quality, and Harrison and Lybecker do not specify on what basis consumers sort between sectors. With the notable exception of Hirth (1999), however, all these studies assume strict enforcement of the non-distribution constraint.

Hirth (1999) analyzes competition between NP and FP firms under three different levels of enforcement. He shows that the credibility of the NP sector is preserved under strict and moderate enforcement of the non-distribution constraint. In the case of weak enforcement, however, for-profits-in-disguise enter the market and the NP status fails to signal high quality production. In Hirth's model consumers who are uninformed about quality patronize NP firms which produce a higher quality and charge a higher price than FP firms. Informed consumers, in contrast, prefer dealing with FP firms. In Hirth's model, this sorting of consumers decreases opportunism in the FP sector and thus positively affects the quality of FP products.

The objectives pursued by NP firms affect equilibrium quality/quantity and price (Harrison and Lybecker 2005; Brhlíková 2006). Since the NP firms' objectives are mainly determined by funding entrepreneurs and those who manage the firms (Young 1983), it is important to know what entrepreneurial type will be attracted to the NP sector. The entrepreneurial choice of the ownership form, which is omitted in Hirth's analysis, affects the competitive outcome. (Glaeser and Shleifer) show that the quality delivered by NP firms is indeed higher than the FP quality even in the case when a self-interested entrepreneur enters the NP sector. We show that the quality difference diminishes under weak enforcement of the nondistribution constraint. The interesting question of how would competition affect the choice of quality under weak enforcement remains. Would the competition discipline entrepreneurs entering the NP sector? How much can they cheat to keep 
the NP signal credible?

\section{Conclusion}

Motivated by the empirical evidence that shows significant gaps in law and regulations of NP entities and further, the enforcement of these regulations, we studied the impact of the non-distribution constraint and its enforcement on the entrepreneurial choice between NP and FP ownership form. We also analyzed the consequences of weak enforcement of the non-distribution constraint for the quality and price of the products delivered by the NP entrepreneur.

We find that besides the possibility to consume perks, it is its combination with weak enforcement of the non-distribution constraint that makes the NP sector unequivocally more attractive to entrepreneurs. Moreover, the NP sector thus attracts entrepreneurial types that might not be willing to pursue objectives that are usually attributed to NP organizations. Entrepreneurs motivated by perks have also incentives to maximize profits although their incentives to do so are weaker than incentives of FP entrepreneurs. The strength of incentives, however, depends on the definition of the non-distribution constraint as well as on its enforcement that clearly affect the quality delivered by NPs. The model shows that the quality delivered by the NP firm under weak enforcement is lower than that of the NP firm under strict enforcement but higher than the quality delivered by a FP firm.

In this paper we do not analyze the entrepreneurial choice under mixed competition. It would be interesting to see how competition affects the entrepreneurial choice under weak enforcement when NP and FP firms compete. Therefore it would be beneficial to combine the entrepreneurial choice model with a model of mixed competition. This is a topic of current research. 


\section{References}

Akerlof, G. A. (1970). The market for "lemons": Quality, uncertainty and the market mechanism. Quarterly Journal of Economics 84 (3), 488-500.

Bilodeau, M. and A. Slivinski (1998). Rational nonprofit entrepreneurship. Journal of Economics and Management Strategy 7(4), 551-571.

Bradley, B., P. Jansen, and L. Silverman (2003). The nonprofit sector's $\$ 100$ billion opportunity. Harvard Business Review 81 (5), 94-103.

Brhlikova, P. (2004a). Models of competition between one nonprofit and one for-profit firm. CERGE-EI Working Paper no. 240.

Brhlikova, P. (2004b). The nonprofit sector in the Czech Republic. CERGE-EI Discussion Paper no. 128.

Brhlíková, P. (2006). Mixed competition under various nonprofit objectives and various cost configurations. Manuscript.

CVNS (Ed.) (2004). Ekonomické výsledky nadačních subjektio v roce 2002 (Economic results of foundation-like organizations in 2002). Brno: Centrum pro výzkum neziskového sektoru.

CVNS (Ed.) (2005). Ekonomické výsledky obecně prospěšných společností v roce 2003 (Economic results of public benefit oraganizations in 2003). Brno: Centrum pro výzkum neziskového sektoru.

Eckel, C. and R. Steinberg (1993). Competition, performance, and public policy towards nonprofits. In D. Hammack and D. Young (Eds.), Nonprofit Organizations in the Marketplace, pp. 57-81. Jossey-Bass, Inc.

Facchina, B., E. A. Showell, and J. E. Stone (1993). Privileges and exemptions enjoyed by nonprofit organizations. University of San Francisco Law Review 28, $85-121$. 
Fric, P. and R. Goulli (2001). Neziskový sektor v České republice (Nonprofit sector in the Czech Republic). Praha: Eurolex Bohemia.

Friesner, D. and R. Rosenman (2001). The property rights theory of the firm and mixed competition: A counter-example in the US health care industry. International Journal of the Economics of Business 8(3), 437-450.

Gibelman, M. and S. R. Gelman (2004). A loss of credibility: Patterns of wrongdoing among nongovernmental organizations. Voluntas 15 (5), 355-381.

Glaeser, E. L. and A. Shleifer (2001). Not-for-profit entrepreneurs. Journal of Public Economics 81, 99-115.

Hall, P. D. (1992). Inventing the nonprofit sector and other essays on philanthropy, voluntarism, and nonprofit organizations. Baltimore, MD: Johns Hopkins University Press.

Hansmann, H. B. (1980). The role of nonprofit enterprise. Yale Law Journal 89, $835-901$.

Harrison, T. D. and K. M. Lybecker (2005). The effect of the nonprofit motive on hospital competitive behavior. Contributions to Economic Analysis 8 Policy 4(1), Article 3.

Heal, G. (1976). Do bad products drive out good? Quarterly Journal of Economics 90(3), 499-503.

Hirth, R. A. (1999). Consumer information and competition between nonprofit and for-profit nursing homes. Journal of Health Economics 18, 219-240.

Holtmann, A. G. and S. G. Ullmann (1993). Transaction costs, uncertainty, and not-for-profit organizations: The case of nursing homes. In A. Ben-Ner and B. Gui (Eds.), The Nonprofit Sector in the Mixed Economy, pp. 149-162. Ann Arbor: University of Michigan Press. 
Klein, B. and K. B. Leffler (1981). The role of market forces in assuring contractual performance. Journal of Political Economy 89(41), 615-641.

Lien, D. (2002). Competition between nonprofit and for-profit firms. International Journal of Business and Economics 1(3), 193-207.

Liu, Y. and C. B. Weinberg (2004). Are nonprofits unfair competitors for business: An analytical approach. Journal of Public Policy 63 Marketing 23(1), $65-79$.

Mauser, E. (1998). The importance of organizational form: Parent perceptions versus reality in the day care industry. In W. W. Powell and E. S. Clemens (Eds.), Private Action and the Public Good, pp. 124-133. New Haven, CT: Yale University Press.

Newhouse, J. P. (1970). Toward a theory of nonprofit institutions: An economic model of a hospital. American Economic Review 60(1), 64-74.

Ortmann, A. and D. Colander (1997). A simple principal-agent game for the classroom. Economic Inquiry 35(2), 443-450.

Ortmann, A. and M. Schlesinger (2003). Trust, repute, and the role of nonprofit enterprise. In H. Anheier and A. Ben-Ner (Eds.), The Study of Nonprofit Enterprise: Theories and Approaches, pp. 77-114. New York: Kluwer.

Ortmann, A., K. Svitkova, and A. Krnacova (2005). Certification as a viable quality assurance mechanism in transition economies. In Feasibility study on establishing a certification system for nonprofit organizations in the Czech Republic, pp. 7-46. Prague: Transparency International-Czech Republic.

Roland, G. and T. Verdier (2003). Law enforcement in transition. European Economic Review 47(4), 669-685.

Rose-Ackerman, S. (1996). Altruism, nonprofits, and economic theory. Journal of Economic Literature 34, 701-728. 
Salamon, L. M., H. K. Anheier, and Associates (1999). Global Civil Society: Dimensions of the Nonprofit Sector. Baltimore, MD: Johns Hopkins Center for Civil Society Studies.

Senate Finance Committee Staff (2004). Staff discussion draft (white paper). http://www.finance. senate.gov/hearings/testimony/2004test/ 062204stfdis.pdf.

Steinberg, R. (1993). Public policy and the performance of nonprofit organizations: A general framework. Nonprofit and Voluntary Sector Quarterly 22(1), $13-32$.

USAID (2002). NGO sustainability index. http://www.usaid.gov/ locations/europe_eurasia/dem_gov/ngoindex/2002/czech.pdf.

Weisbrod, B. (1975). Toward a theory of the voluntary nonprofit sector in a three-sector economy. In E. Phelps (Ed.), Altruism, Morality, and Economic Theory. New York: Russell Sage Foundation.

Weisbrod, B. (1988). The nonprofit economy. Cambridge, MA: Harvard University Press.

Young, D. R. (1983). If not for profit, for what? Lexington, MA: Heath. 
Individual researchers, as well as the on-line and printed versions of the CERGE-EI Working Papers (including their dissemination) were supported from the following institutional grants:

- Center of Advanced Political Economy Research [Centrum pro pokročilá politicko-ekonomická studia], No. LC542, (2005-2009),

- Economic Aspects of EU and EMU Entry [Ekonomické aspekty vstupu do Evropské unie a Evropské měnové unie], No. AVOZ70850503, (2005-2010);

- Economic Impact of European Integration on the Czech Republic [Ekonomické dopady evropské integrace na ČR], No. MSM0021620846, (2005-2011);

Specific research support and/or other grants the researchers/publications benefited from are acknowledged at the beginning of the Paper.

(c) Petra Brhlíková, Andreas Ortmann, 2006

All rights reserved. No part of this publication may be reproduced, stored in a retrieval system or transmitted in any form or by any means, electronic, mechanical or photocopying, recording, or otherwise without the prior permission of the publisher.

Published by

Charles University in Prague, Center for Economic Research and Graduate Education (CERGE) and

Economics Institute (EI), Academy of Sciences of the Czech Republic

CERGE-El, Politických vězňů 7, 11121 Prague 1, tel.: +420 224005 153, Czech Republic.

Printed by CERGE-EI, Prague

Subscription: CERGE-El homepage: http://www.cerge-ei.cz

Editors: Directors of CERGE and EI

Managing editors: Deputy Directors for Research of CERGE and EI

ISSN 1211-3298

ISBN 80-7343-095-9 (Univerzita Karlova. Centrum pro ekonomický výzkum a doktorské studium) ISBN 80-7344-084-9 (Akademie věd České republiky. Národohospodářský ústav) 
CERGE-EI

P.O.BOX 882

Politických vězňů 7

11121 Praha 1

Czech Republic http://www.cerge-ei.cz 